\title{
Creative Careers and Territorial Development: The Role of Networks and Relational Proximity in Fashion Design
}

\author{
Diane-Gabrielle Tremblay \\ Teluq, University of Quebec, 100 Sherbrooke Street West, Montreal, QC, Canada H2X 3P2 \\ Correspondence should be addressed to Diane-Gabrielle Tremblay, dgtrembl@teluq.ca \\ Received 8 July 2012; Accepted 3 September 2012 \\ Academic Editor: Jianfa Shen
}

Copyright ( $) 2012$ Diane-Gabrielle Tremblay. This is an open access article distributed under the Creative Commons Attribution License, which permits unrestricted use, distribution, and reproduction in any medium, provided the original work is properly cited.

Geater Montreal is the third largest city in North America for the garment industry in terms of labour force, after Los Angeles and New York. The industry has however changed partly into a service industry, centered on fashion design, with a focus on international competitiveness but also the role of fashion in Montreal's economic and territorial development. Our article analyzes careers in the fashion design sector, sheds light on the evolution of creative sectors, and shows how these sectors could be better supported to favor local development, as neighborhoods and space design appear important in these creative sectors. We situate our analysis in the theoretical context of career theories, and analyze key moments in careers and the role of intermediate organizations and government programs in supporting these careers. Our paper makes a contribution to our knowledge of career paths in the fashion industry, but also to the role of relational proximity in supporting these careers, and thus local development. It highlights the importance of personal connections, the milieu in which the individual works and functions, the creativity of the individual, as well as the role of the local support organizations and professional associations, including agencies of the provincial government.

\section{Introduction}

Greater Montreal is the third largest city in North America for the volume represented by the garment industry in terms of labour force, after Los Angeles and New York, and according to recent statistics, Montreal has $75 \%$ of jobs in the garment industry in Quebec (Canada), with 50,000 jobs in manufacturing, distribution, and retail. If, a few years ago, statistics from the garment manufacturing industry led to believe that it was declining, a major study of the Human Resources Council of the Garment Industry [1] indicates that the industry is rather transforming itself. In recent years, industry has changed partly into a service industry, centered on fashion design, that is, design within manufacturing companies, but also a strong focus on selfemployed fashion designers who are seen as a source of international competitiveness and contribute to highlight the role of fashion in Montreal's economic and territorial development.

This focus on design is important given the important competition from low-wage countries for the traditional clothing manufacturing, but also the important competition from the top tier fashion cities, such as Paris, Milan, and New York. Montreal has tried to find a niche in between these two extremes, defining itself as a second tier fashion city, with no too expensive (i.e., not "Haute Couture") but original fashion design, including sectors such as ecological fashion production with biological cotton or reusing textiles or fur (the case of Harricana). As Montreal has received the title of "UNESCO City of Design," the City also tries to support the various design sectors, including fashion, as this is part of what it sees as the Creative City image, which it wants to put forward in order to differentiate itself from other cities, to develop itself on the basis of design creativity, putting forward fashion design with other artistic or creative sectors as part of an important economic development strategy. This focus on fashion is also part of the urban regeneration process in Montreal, which brings the city to favor creative activities and design sectors in this process $[2,3]$.

Its from this perspective that we were interested in fashion designers' careers and how the local environment can support their career development and thus, local/territorial 
development. The purpose of the paper is to understand careers in the fashion design sector, to shed light on the more general transformation of careers and work [4-6], following Menger [7], who presents creative or artistic careers as precursors of career trends, and to determine how these careers could be better supported to favor local development of this sector, as neighborhoods and space design appear important in this sector [8].

We will situate our analysis in the theoretical context of career theory's recent evolution, from essentially centered on organizational careers towards boundaryless careers. From an empirical perspective, we analyze key moments in these careers and the role of intermediate organizations and government programs in supporting these careers. We will then determine to what extent neighborhoods and relational proximity could support these careers, and thus, local development, but we start with some elements of career theories to determine how analysis of fashion designers' careers, as other creative careers, can be understood in this context and contribute to the theory.

\section{Career Theory}

The theory of internal labor markets and the context of large hierarchical firm have traditionally been at the center of career theory, which has focused on the organizational career. Horizontal and other forms of mobility [9] have not been studied as much since they were traditionally viewed as lack of advancement and thus of career. Recently, this model has been questioned $[10,11]$, and some authors have shown the importance of different anchors that define the various stages of a career [12] and have begun to put forward a new vision of careers referring to the "boundaryless careers" [13$15]$, or the "nomadic" careers $[16,17]$.

In this boundaryless careers approach, there are three elements which interact with each other and contribute to career mobility: (a) knowing how (knowledge, abilities, and acquired routines), (b) knowing whom (privileged relationships, contacts, and social networks), and (c) knowing why (interests, values, and identity construction).

This new vision of careers is focused on learning, reputation building, and identity construction [18], and this appears pertinent for sectors such as fashion and other creative sectors, where information, ways of seeing things, ways of thinking, tricks of the trade, or job opportunities are transmitted through the network and social relations [18].

The concept of the boundaryless or protean careers [19] thus leads to an understanding of careers as being built largely on experience and networks (knowing whom), which contributes to develop a "career capital," which in turn can lead to access to some specific institutional or professional networks [16]. For many people, however, these boundaryless careers can actually be rather precarious careers, as it is not always easy to develop social capital and career capital. Career capital results from an accumulation of career competencies and this can contribute to building a reputation in a creative career, but at the same time possibly contribute to the neutralization or at least reduction of risk, an important dimension in a fashion and other creative careers. This new vision of careers thus opens up on the importance of networks and relational proximity for support to these careers and, in turn, to territorial development.

\section{Risk and Relational Proximity in Designer's Creative Career}

In general, creative production is based on project-based organizations and labor flexibility [20]. As project-based and creative-based at the same time, creative organizations face many kinds of intense risks. These organizations therefore tend to organize in clusters and networks as a way of dealing with this variety of risks [21]. We will start by the issue of risks to explain how risk is omnipresent in this creative industry of fashion design and we will then see how it is possible to deal with risk through relational proximity and local intermediate organizations' support.

Fashion designer careers are prone to risk. Indeed, the designers' efforts are continuously confronted with risky or uncertain contexts. Ephemerality, ambivalence, and ambiguity make fashion design a highly uncertain and risky business. Creators of creative designs in a creative industry such as fashion are constantly embedded in an uncertain context [22]. Aesthetic judgment on fashion is regularly the subject of taste volatility and contestation [23-25]. Fashion design can be of high quality but may not always have commercial value and the contrary is right as well $[26,27]$. Thus, not only is the creative process uncertain $[7,28,29]$, but the market demand is also uncertain, and it is sometimes difficult for fashion designers to reconcile both objectives, that of a creative career and that of a entrepreneurial business. However, the network and intermediate organization's support can be seen as a risk filter or risk reduction factor [30-32] as we will see in our results.

Rantisi and Leslie [8] analyze the workplaces and space design of various new sectors, including the fashion sector. They show that the public spaces and the neighbourhood in which designers locate are important to them as this can have an impact on the chance encounters and interactions between creative workers, which can also be seen as a source of cooperation, interdependencies, and risk reduction. In our view, intermediary support organizations should try to valorize such elements in the neighborhoods in order to support fashion designers' careers, and we sought out to see if this was the case.

Most authors in career theory, such as Super [33] or Hall and Goodale [34], divide careers into four phases: exploration (learning period), mastery (development), maintenance (routine), and disengagement (retreat). While this vision of four successive stages is contested by others, it does constitute an important reference. Weick [35] considers there is no empirical basis to confirm the succession of these phases, and the new boundaryless career theories would tend to indicate that lines are more blurred and there is no regular succession of phases.

In industrial and creative cluster studies [36], researchers have been highlighting the role of relational proximity, 
after that of physical or geographical proximity. Actually, both forms of proximity appear to be intertwined and possibly more so in creative sectors. Relational proximity has to do with personal and organizational relations between individuals, and is thus more than physical proximity. Researchers agree that physical proximity does not appear to automatically have an influence on a sector (or designers') capacity to be creative. Indeed, personal interactions and access to information networks are key factors when a firm or an individual decides to create [37]. In other words, physically cohabiting with other creators may be of less importance than what was originally thought, but it can impact on the capacity to create if it also gives way to relational proximity.

To conclude, in creative industries, the creative process as well as the consumption part (sale of designs) of the process are prone with risk and uncertainty $[28,29,38,39]$. We will therefore try to see how designers' careers fit into the above typologies and how the local environment and networks can eventually contribute to reduce risk in fashion design.

\section{Methodology}

Theory maintains that individuals construct their careers by giving meaning to their performance. Personality types and transitions of their development deal with what the person did and how he/she did it to construct a career [40] Since we are interested in designers' careers, and this is to a certain extent an exploratory research, we have chosen a qualitative method that gives voice to the designers, leaving an important place for quotes in our paper.

Our research is based on a case study of the fashion industry in Montreal. We conducted a literature review on the fashion industry, interviews with 10 intermediary support organizations as well as garment firms and fashion designers, in 2008-9 and in 2011. In this paper, we focus mainly on 20 interviews with fashion designers, and 6 with intermediary support organizations dealing with the fashion sector, to determine the role of relationships, relational proximity, and intermediary organizations in creative career construction. The interviews were transcribed, coded with Nvivo, and analyzed by groupings according to the themes of the interview.

\section{Results}

We found that while the fashion designers have risky and uncertain careers, they are passionate about their career, and while they do appreciate some support from intermediate support organizations or governmental programs, they are not always well informed of these possibilities, maybe because they are quite independent in the pursuit of their career.

From this point of view, they do fit the boundaryless or nomadic model to a certain extent, although when they develop their own brand and firm, they tend to stabilize and remain in this work status, as we will see. Indeed, as there is strong instability and sometimes failure in these careers and entrepreneurial ventures of designers, it appears that the role of networks and intermediary support organizations could be better known and used to favor career and local territorial development through entrepreneurial activities in fashion design.

5.1. Entering the Field and the Role of Associations. For many designers, it is the passion for fashion or garment design that opens the door into the world of entrepreneurship as a designer. Passion for fashion and creation nourishes designers and they proceed through various steps to a personal clothing line and eventually to be present in a few shops or have their own: as one designer mentions:

It started with my individual passion for fashion. As a graduate, I worked in companies. And from there, I created my own line. Then in 2005, I rented a small space with designers, and then I started to make a line that I presented at the fashion week and that's where I was selected for a fashion show, my first was for autumn/winter 2006. This was done in 2005. And then from there, I created my company called D13. And here and there, I made small productions; in fact, I do all my designs, concepts, I had a seamstress to help me make my samples... Once, I dealt with a "patronniste", but most designs I who make them myself, all designs and patterns, and for samples there is a designer who comes up in my studio as I am fully equipped, I have a machine, I have a cutting table and everything. And here I present my ideas in the making, I present my online buyers, shops that support us. I have my clothes in some stores. It's small collections, it is not really big production, just for 4 shops. (D 13)

In several comments, it appears that there are many benefits for young designers who start in the business to be part of an association, a chamber of commerce, or to attend local neighborhood initiatives. They are gathering places and sources of information, a good way to be known, but also an approach that promotes informal meetings that are "source of ideas." It even seems there would be a new mindset among young designers.

Visibilitiy, perhaps? To be known more, that's all. Well, when you meet ten people, they will automatically say, "you work for? D2." So ten people know that D2 exists, it is just that. (D2)

Often informal gatherings, I find more, more... generating ideas and not formal meetings scheduled. Formal meetings, it is information we are given, while often informal meetings between $u s, .$. we find ideas, interesting solutions not found in formal meetings. (D12)

Well, it's very important, there should be more of it... I think we have it.. . but people do not know us, the public does not know us. (D7) 
I think... Maybe a new mindset that is being created ... to talk with the designers. . these last years. Because... I think everyone realizes that it's so hard to survive each in his corner. (D17)

We found a fine example of local support initiatives from the Economic Forum of Verdun, and the Plateau Mont-Royal, original initiatives that foster networking and sometimes joint initiatives between designers, even if the world of fashion is rather individualistic in general.

The Midi-motivation (Verdun) something that was organized here so that you network, make contacts, ... tell me about your business, ... contacts, everything.: "Ah, I have friends who wanted to do something...". We start talking and exchanging ideas. Because the first time you go, you're a little embarrassed too. But after everyone knows each other and you get to be known There is also ... this Prize in Verdun. Every year we participate, we win, we do not win, it does not matter... But it's good, it's motivating for people like us. (D10)

First, it allows me to see all the services in my neighborhood, it helps to know the diversity of products, see also those who open, those who close, to see changes in the area. It's each his turn, right now, there is a rebirth of the neighborhood, sometimes there are neighborhoods that fall as the Plateau Mont-Royal in the 60s, and they relive. D3

Again, it seems that we must be proactive and take the initiative to do it yourself, to get information. In the area of fashion design, many feel they must build their own careers, get information, and so forth.

It's more interesting with them (The Chamber of Commerce). But I have to call, they do not do it; when you have members, normally, you should take care of them, send some information. (D1)

And when things start to work for a designer, there is a significant challenge, to expand a business without losing the creative side.

5.2. Developing a Business While Maintaining the Creative Activities: A Challenge! A key challenge for fashion designers is to balance activities on the creation and business sides. Some fashion designers are able to reconcile their creativity and the entrepreneurial aspect, but this is not always simple. The desire for freedom animates the career of one designer.

When we met, it was she who approached me. She had a design concept, I had an idea ... she had the marketing, sales an all that. She approached me and said, "For me it would be interesting to do business with you, what do you think? At first we went and had a glass of wine, we thought things out and all that. we bought stuff, I did not have mega-expectations. Then at one point I had to choose, the job I wanted. I could go faster in large companies. I could have a job... in the head office. But now, I would not really made here. But I would not work for others. I wanted to have some freedom. That's the choice I made. No money, but live freely, not a very good salary but not having someone on my back. (D1)

We observed another case where an association of people and skills has established the right conditions to start the business "by accident" or a combination of circumstances.

She has a master's degree in marketing. So, Claude, she was studying, and I, at the time, I was a social worker, between social work and theater. And her mother who lived in Paris, she had a clothing company for children. She wanted us to develop it here... in Canada. It did not interest us at all. Then one day, she found an agent from Montreal in a salon in Paris and he said "I will be your agent in Montreal." Ok, so within three, four days, he sold for twenty, thirty thousand dollars. Waah, it's interesting we thought... So we got into it, the agent sold. Twice a year, we received the goods at home, so it was an accident in the beginning, the mother in law. (D6)

Some people have other work experiences and training before starting their own business. For one designer, experience and support of his peers allowed him to achieve professional development. He does not see his career as a lifelong commitment to one employer, but as a sale of services and skills to carry out his own professional project, "to make tailor-made creation," which has motivated him from a young age. This confirms the importance of networks in the development of a career.

I graduated from Lasalle College in Creation and costuming, for theater and cinema. In college, I developed my sewing, design, research, history and all. On the most fantastic themes. And in real life, my first real experience of, say, industrial, commercial work, it was Buffalo Jeans. So I got to know the market, large scale production.... It's things that I had never touched before. (...) Just a year and a half. But before Buffalo Jeans, I always did tailor-made. That's another aspect. Since I was young, 16, 17, clients came to see me, I made them dresses, creating tailor-made. Then, over time, I varied, I do swimwear, costumes, luxury wedding gowns. (...) Then, officially, I started my business, it was in autumn 2005. But first, what is important in my experiments, after Buffalo, I did an internship with Valerie Dumaine, a designer of Montreal. She showed the local side, the production and creation. So it really helped me in starting my business. She has shared many 
suppliers, knowledge... She is a very important person in the field in Montreal fashion right now, which is good. (D5)

For some designers, the initial work experience does not always live up to their expectations, and the experience of working as an assistant designer has been disappointing. One of these designers has then used intermediary organizations, such as Emploi-Québec (Québec Department of Employment) and SODEC (Society for support to cultural industries) to prepare her own career, preparing her business plan while being paid minimally; she wanted to make her work meaningful while controlling her environment.

It was in 2006. I got a job as an assistant designer for three months, but this was ridiculous. It is not well paid. I was sewing and all that. It's not really what I wanted to do. Then, it was after that, I ... I've always done figure skating, and I've always had the idea of making a skating clothing line. So at this point in my life, I really did not know where I was going, I went to EmploiQuébec, there were grants from SODEC, Grants for Self-Employment Assistance, so I applied, but I could not apply it in fashion generally, unless it is for a target audience with a technical fabric, so figure skating fit in perfectly. I used the SelfEmployment Assistance which is a year's salary, 40 hours a week minimum wage, to expand the business, business plan, all that. It's, I did that for a year. I was developing my D7 company on the side... Then a year later, in September 2007, I got the opportunity to have a shop on St-Denis, a local shop with a workshop, soI hired my first employee, a seamstress. Then, my grant ended in January. This grant really helped me to live from my work, starting the company (...) I got the chance to sell my clothes. So, I started with 7 styles that I had already prepared at school, I developed them, produced them, then I sold them. So I'm at the fourth collection since we opened the shop, it'll soon be 2 years. It's very... new. But it was a pretty impressive success, I was not expecting it to work so much. So I now have a workshop outside the store, because it is too small, for the inventory. I hired a second assistant, and the store is much larger. (D7)

I would say it is a combination of everything. I always wanted to do that. The work experience I had, although I really hated all these jobs I had, I got a lot of experience so I'm happy, and then I got my own line. My trip to Berlin really inspired me a lot, it was decisive. When I returned, I started my line. And since I got my sales agency in Vancouver, it really boosted sales. (D14)

Here again, a designer uses the resources of local intermediary organizations to make a business plan and start a business after having some experience in another firm. In fact, there are many who have used the services of SAJE (support to small business in the form of self-employment).
I worked seven and a half years, I did some training with F Company, SAJE, to make a business plan, all that. Then the project began in June 2006. D9 was founded in 2007, because I had to go see first the feasibility, but hey, I had to create my line and structure everything. (D9)

We wanted to identify key moments and phases of the career of a designer, but for many it is difficult to identify really decisive key moments and phases. If some can identify an important event, press event, then a national event for example, the career phases seem to be somewhat blurred, and the exploration phase often reappears when new projects or ideas surface. "Success" also takes on different forms; it can be achieved through a presence in an important magazine, a TV show, a national or international newspaper, and a huge recognition in the media. But for others, these aspects are irrelevant. From creation to production, and sales, they just invest themselves and find that it is "rewarding." This seems to be closer to Weick's [35] view than to that identifying a series of successive stages in a career $[33,34]$.

Milestones in my career? All steps are important. Yes, because ... When you change from one field to another, you discover much,... the evolution of the garment, a product from $A$ to $Z$, and different ways, because companies are different from one another, because the products also are different, the approaches are different. what is good, working in companies, is that we choose our own styles and creations, we follow up with our clothes, that's very interesting, very rewarding. (D13)

There are those who focus more on the spirit that animates them; the values that guide choices and adjustments. Thus, one explains his choice of career and says his artistic "creativity, originality, and aesthetics are reformulated and reinvented in the prism of passions," in relation to history, photography, and dance.

I found nothing in men's clothes for me... there was always the golf look, the businessman look, the jeans look, the gay look, and so forth ... So I told myself I love history,... I would not necessarily get dressed like Mozart, but. . there are not many traditional costumes in Quebec... we do not have the Indian Sari, the Scottish Kilt, the Japanese kimono, so I thought what is the design in Quebec, what is it that can be done as an alternative fashion style for men to break their usual look, without falling into the transparent, crazy styles that look gay. I saw Gauthier's work in the 80s and I thought: "well that's fine but nobody will buy it, nobody can wear it, or only for one hour on one night. So I thought I really must make a collection... (D3)

Photography is always a passion just as clothing. I studied fashion design. Later, mixing the two, the two disciplines. In photography, I have no 
training. But I always liked that. So that's one of my passions. (D8)

I know that dance led me to movement. And I always liked ... the movement in clothing, for me, clothes have to move. It's not cardboard box tailoring. For me, it must move. Dance has served me well. And the rest is... a lot of intuition, fashion takes a lot of instinct, you must always be a little ahead of everybody. But... we work all day. So we certainly have a lead over everyone.... Now, there's glamor, there is too much glamor... but we will return to the severe. Because everything is too glamorous. That's the kind of intuition I use. Intuition ... artistic dancer or ... It's an intuition. (D12)

The creation of the entire garment in its own space is important to some and the creative dimension is put forward, compared with the work of a writer who has to write his ideas on paper and work on them.

Everything is created here. As a writer who writes a line every day in his book, I write down my ideas. This is my culture, my personal baggage. Yes, I am very influenced by the past, costume history, history of art. Sociology through the ages, which could influence a wedding dress, a ball gown... to know many religions... I really need to know history. Because it's sure my sources of inspiration are really... in art history, costume history ... I read no fashion magazines, I do not look at fashion magazines. (D3)

For another designer, it is also a questioning of "life," the desire to change the world and do "something positive" in society. He wants to have a commitment and support a social cause.

In fact, it is a challenge in my life. I thought the world was wrong and I had to do something positive... I was working ... 9 to 5, I got up, I worked, I ate, I worked. I thought it was too routine. I had to bring something to society, more than just work and have money. And then, there were opportunities that presented themselves, I met Pascal. After that, I worked part time. Where I worked, they knew what I was doing and they were supportive. They said: "Go ahead with your project!". (D11)

For many, one of the key moments in the career is the moment of recognition from their peers in fashion shows and other visual events, such as photo shootings, that highlight one's creativity or contribute to reputation.

The milestones ...the beginning of D12 was very striking, because it was super creative. It had a "hell of a reputation" in Montreal. It was really recognized as a leader in new couture. It was the theatrical fashion-shows. It was good, though challenging, this period. Then a musical comedy where your name appears for the costumes...everyone congratulates you... as it happened recently in Paris, my god!... There are all sorts of things. But let us say that the beginnings were very, very strong. It started really in the 70's, 80 's, fashion journalists were really hung up on us. (D12)

It is happening now. Because right now, we are really growing ... it really has doubled since last year,... yesterday we did our 2010 shoot. . the collection will be more interesting than ever. I would say, right now, there really is a breakthrough, and we are heading in the right direction. (D1)

This brings us to the role of reputation in building careers of designers, since it is related to key moments of recognition and highlights again the role of networks and relational proximity in the development of a career, and eventually in local development as well.

5.3. The Role of Reputation in Career Construction. In the writings that deal with reputation in connection with careers, many agree that reputation is an intangible asset, linked strongly to the perceptions and public response to the creativity of the company [41], while others will consider reputation to be mainly related to fame, whether this is justified or not ([42] page 431). For Yagoubi [43], relationships based on recognition of social esteem are a prerequisite for professional achievement and strengthening the fashion designers and creative careers in general. There appear to be four conditions associated with recognition [43]:

(i) expectations of the environment,

(ii) cooperation with peers,

(iii) investment in the community,

(iv) and individual self-realization.

For many of our designers, reputation management involves a certain visibility, reputation, and credibility of their organization. This is what [43] is called "spectacularization" or highlighting of social recognition. In this environment, designers are somehow staged in a show; fashion designers find themselves in various events:

We did three big shows: Montreal Crafts Fair, the One of a kind in Toronto and the Vancouver Circle Craft is new this year. ...that, plus the shops, we need big productions to go in these places to sell our goods. It goes very quickly. We make a lot of money... (D1)

For this designer, reputation is one component of branding. His reputation demonstrates his ability to provide meaningful results for stakeholders in the fashion world.

It's been almost 20 years, in parallel with the CEGEP or other projects, it's been 20 years that 
I've worked for other designers, I have built several brands that still exist today. One of the highlights of my entry into the world of Québec creators is when I was manager of the Revenge store in 1989, on St. Denis. At the time, the store represented Quebec products, like a museum. (D3)

For the same designer, reputation also derives above all from his creativity, which is influenced by his childhood, music, and fashion history. In fact, this is as much the designer's image as a way to take his place in history.

\begin{abstract}
Obviously, my childhood, my past, classical music has influenced my brand, that's for sure, ... history of costume, music history, fashion history, all influence the choice of materials, I work with all religions today.... It is really a way to position myself in history. Many brands do not know where they are located in history. In terms of design, many do not know if anyone has done the same before, if the product will last one season, or 100 years, or if it's something... that was created just for 2 weeks. There are difficulties, both for people to position themselves in the history of costume, to ensure a good choice of buttons, buttonholes, collars, false or real pockets, ...that's what will influence the strength of a brand. (D3)
\end{abstract}

For one designer, reputation management is essentially using different initiatives to orchestrate more subtle public relations, such as "word of mouth," to promote his brand or his corporate reputation. Several emerging designers opt for this approach.

In fact, my product, it is the same from the beginning, I have a fairly underground approach to the promotion, I use a lot of word of mouth. So with the quality, as many customers love what I do, my client network widens this way. My shops also helped me. The distribution to stores, customers that I did not necessarily access, they will discover D5. Ah, D5, what is it? They start to know me in this way alongside other brands. (D5)

For another designer, reputation is seen from the perspective of social identity, as an important resource with a significant impact on performance and reputation as an international brand. She tries to transmit her values and show she is sincere in "beautiful catalogs."

Competitive advantage, first, I think we have succeeded in building a strong identity. D6 is synonymous with design, creativity, innovation. The design is extremely important to us, we make clothes also to have fun and make beautiful things. This... is also reinforced by beautiful catalogs. The last one was done in Russia. So that takes us on the map with our global brand reputations, not only local, Quebec and all that. (...) And we do two catalogs a year, there are catalogs shot in different countries. We went to Cuba, Mongolia, Morocco,
Peru, places like this. So all this reinforces that identity. We do not compete on price. Our market is not a high volume market. It's a little niche market... (D6)

This leads to confirm the importance of local support not only in developing local markets, but also for the international market, which is essential for many designers to succeed, as the local market is to a certain extent quite limited. Some intermediary organizations (SODEC, SAGE) can offer support to young designers wishing to develop international activities, but they again appear to be known to only a few designers, usually those who have been present in the market for a few years. There is surely a niche to develop here, in terms of support to young designers for access to international markets which can support the development of their career and, in turn, contribute to local/territorial development in the city where the designer is established.

\section{Conclusion}

We found that while fashion designers have risky and uncertain careers, they are passionate about their career, and while they do appreciate some support from intermediate support organizations or governmental programs, they are clearly not well informed and appear to be quite independent in the pursuit of their career. From this point of view, they do fit the boundaryless or nomadic model [13-15] to a certain extent, although when they develop their own brand and firm, they tend to stabilize and remain in this work status. The analysis of these careers shows that the reality may often be between the traditional organizational career and the boundaryless/nomadic career.

Our study of the fashion designers' careers shows that it is apparently difficult for them to define the various stages of a career [12]. The development of a reputation, of a "brand," is extremely important for them and we find that this can be done in different ways and take more or less time, at different stages in the career, according to the various individuals. While some may have created their firm or bought a shop early on in their career, others spent more time in a large firm, to learn the tricks of the trade.

Our interviews confirm the vision of the three Ks (knowing whom, why, and how) and their importance in building a career, but these elements have more or less importance according to the individual designer. All are animated by a clear passion for their work (knowing why: interests, values, and identity construction), and it appears essential of course to have the know-how, and then for many knowing whom (privileged relationships, contacts, and social networks) does come out as an important dimension to build a career and contribute to local/territorial development. It can be either the mentor who offers to share knowledge, access to precious resources such as good seamstresses, information on activities, and shows and it can sometimes be closer to the media world, in terms of access to press, fashion media, and the like. There is some contribution from intermediary organizations, but this source of support is rather little known by designers, especially at the start of their careers, 
while this could be of use to them. As there are nonnegligible barriers to the entry of the profession, it would be important for designers to be better informed of the support they can get.

As we know, fashion design as any other art form or artistic career can be the subject of contestation and taste volatility. It can be of high quality but may not always be of commercial value, which makes it a rather risky endeavour. However, it is interesting to see that many designers (in particular D3) consider it more important to establish an identity, to place oneself in a historical perspective and not be so sensitive to taste volatility in order to succeed and establish oneself in the local market.

Thus, while the market demand and the creative process are recognized as uncertain and while it is sometimes difficult for fashion designers to reconcile both objectives, one of a creative career and the other of an entrepreneurial business, it appears that peer or associational support can contribute to reduce uncertainty but local intermediary organizations appear not to be well known by young designers.

In terms of social and practical implications, our results show that young designers do not know the resources that could be available to them, and while more established designers sometimes help out, associations and intermediary organizations are very useful and could be more active in supporting young designers' careers. Indeed, as there is strong instability and sometimes failure in the entrepreneurial ventures of designers, it appears that intermediary support organizations at the local level could help not only the designers themselves, but also simultaneously local and territorial development, as designers boutiques can have an important impact on the local environment, as they do in Mile End and Plateau in Montreal.

On a more general note, this research is interesting not only for the fashion design sector, but also for all creative careers, on which there is relatively little research, while these sectors are considered more important for today's economy and territorial development. Indeed, it sheds light on one of the forms of boundaryless careers, but leads to nuance the vision of permanent voluntary mobility sometimes attached to this theory. It also shows that even in the context of these nomadic careers, individuals still need to develop their skills and experience, and intermediary support organizations or professional associations could do a lot from this point of view. This may also be pertinent for other creative careers in today's economy, and it might be interesting to maintain links between large firms and these nomadic workers, as both can probably gain from continued relations, and these networks could surely benefit the younger workers, in fashion as in other creative industries possibly.

In our view, this new analysis of a type of career often described as boundaryless or nomadic presents interesting elements to understand other creative sectors and their contribution to local economic development. It also highlights the interest of the "knowing why, how, and especially whom" typology in a given context, but also indicates they may be useful for understanding the importance of networks and relational proximity in other creative careers. Our research thus contributes to a better understanding of designers' careers, and also the support which cities and intermediary organizations could bring to them to favor the development of their career and also local/territorial development more largely.

\section{Acknowledgments}

The author wishes to thank the Social Sciences Research Council of Canada and Canada Research Chairs program (http://www.teluq.ca/aruc-gats/) for financial support for this research. The author also want to acknowledge Maryse Larivière's research assistance support. The author would like to thank the two anonymous reviewers for useful suggestions and comments.

\section{References}

[1] CRHIV-Conseil des ressources humaines de l'industrie du vêtement (CRHIV), "Un autre pas vers l'avenir: transformation de l'industrie du vêtement au Canada," in Étude d'Information sur le Marché du Travail 2011, CRHIV, Montréal, Canada, 2011.

[2] G. Tavano Blessi, D. -G. Tremblay, M. Sandri, and T. Pilati, "New trajectories in urban regeneration processes: cultural capital as source of human and social capital accumulationevidence from the case of Tohu in Montreal," Cities. In press.

[3] A. Battaglia and D. G. Tremblay, "22@ and the innovation district in Barcelona and Montreal: a process of clustering development between urban regeneration and economic competitiveness," Urban Studies Research, vol. 2011, Article ID 568159, 17 pages, 2011.

[4] D. G. Tremblay and L. Thomsin, "Mobile work: an analysis of its benefits and drawbacks," International Journal of Work Innovation, vol. 1, no. 1, pp. 100-113, 2012.

[5] D. G. Tremblay and É. Genin, "IT self-employed workers between constraint and flexibility," New Technology, Work and Employment, vol. 25, no. 1, pp. 34-48, 2010.

[6] D. G. Tremblay, “Transformations of work in a global context: employment systems, autonomy, and work-life articulation as main challenges," in Sociology Today; Social Transformations in a Globalizing World, A. Sales, Ed., Sage, Los Angeles, Calif, USA, 2012.

[7] P. M. Menger, "Artists as workers: theoretical and methodological challenges," Poetics, vol. 28, no. 4, pp. 241-254, 2001.

[8] N. M. Rantisi and D. Leslie, "Materiality and creative production: the case of the mile end neighborhood in Montreal," Environment and Planning A, vol. 42, no. 12, pp. 2824-2841, 2010.

[9] J. L. Rosenbaum, “Tournament mobility: career patterns in a corporation," Administrative Science Quarterly, vol. 24, no. 2, pp. 221-241, 1979.

[10] S. E. Sullivan, "The changing nature of careers: a review and research agenda," Journal of Management, vol. 25, no. 3, pp. 457-484, 1999.

[11] S. E. Sullivan and Y. Baruch, "Advances in career theory and research: a critical review and agenda for future exploration," Journal of Management, vol. 35, no. 6, pp. 1542-1571, 2009.

[12] E. H. Schein, "Career anchors revisited: implications for career development in the 21st century," The Academy of Management Executive, vol. 10, no. 4, pp. 80-88, 1996. 
[13] M. B. Arthur, Claman, and R. DeFillippi, "Intelligent enterprise, intelligent careers," The Academy of Management Executive, vol. 9, no. 4, pp. 7-20, 1995.

[14] R. J. DeFillippi and M. B. Arthur, "Paradox in project-based enterprise: the case of film making," California Management Review, vol. 40, no. 2, pp. 125-139, 1998.

[15] R. DeFillippi and M. B. Arthur, "Boundaryless contexts and careers: a competency-based perspective," in The Boundaryless Career: A New Principle for a New Organizational Era, M. B. Arthur and D. M. Rousseau, Eds., Oxford University Press, New York, NY, USA, 1996.

[16] L. Cadin, A. F. Bender, V. Saint-Giniez, and J. Pringle, "Carrières nomades et contextes nationaux," in Revue de Gestion des Ressources Humaines, pp. 76-96, AGRH, Paris, France, 2000.

[17] D. G. Tremblay, "New types of careers in the knowledge economy? Networks and boundaryless jobs as a career strategy in the ICT and multimedia sector," in Communications and Strategies, pp. 81-106, IDATE, Montpellier, France, 2003.

[18] C. Jones and R. J. DeFillippi, "Back to the future in film: combining industry and self-knowledge to meet the career challenges of the 21st century," The Academy of Management Executive, vol. 10, no. 4, pp. 89-103, 1996.

[19] D. T. Hall, "Protean careers of the 21st century," The Academy of Management Executive, vol. 10, no. 4, pp. 8-15, 1996.

[20] M. Lorenzen and L. Frederiksen, "The management of projects and product experimentation: examples from the music industry," European Management Review, vol. 2, no. 3, pp. 198-211, 2005.

[21] R. Kaiser and M. Liecke, "The Munich feature film cluster: the degree of global integration and explanations for its relative success," Industry and Innovation, vol. 14, no. 4, pp. 385-399, 2007.

[22] M. Banks, A. Lovatt, J. O’Connor, and C. Raffo, "Risk and trust in the cultural industries," Geoforum, vol. 31, no. 4, pp. 453464, 2000.

[23] R. Caves, Creative Industries: Contracts between Art and Commerce, Harvard University Press, Cambridge, Mass, USA, 2000.

[24] A. De Vany, Hollywood Economics: How Extreme Uncertainty Shapes the Film Industry, Routledge, London, UK, 2004.

[25] A. S. De Vany and W. D. Walls, "The market for motion pictures: rank, revenue, and survival," Economic Inquiry, vol. 35, no. 4, pp. 783-797, 1997.

[26] P. M. Hirsch, "Cultural industries revisited," Organization Science, vol. 11, no. 3, pp. 356-361, 2000.

[27] P. M. Hirsch, "Processing fads and fashions: an organizationset analysis of cultural industry system," American Journal of Sociology, vol. 4, pp. 639-659, 1972.

[28] P. M. Menger, "Marché du travail artistique et socialisation du risque: le cas des arts et du spectacle," Revue Française de Sociologie, vol. 32, no. 1, pp. 61-74, 1991.

[29] P. M. Menger, "Artistic labor markets and careers," Annual Review of Sociology, vol. 25, pp. 541-574, 1999.

[30] D. Lupton, Risk, Routledge, Abingdon, UK, 1999.

[31] J. L. Klein, D. G. Tremblay, and D. R. Bussiéres, "Community based intermediation and social innovation. A case study in Montreal's apparel sector," International Journal of Technology Management, vol. 51, no. 1, pp. 121-138, 2010.

[32] J. L. Klein, D. G. Tremblay, J. M. Fontan, and N. Guay, "The uniqueness of the Montreal fur industry in an apparel sector adrift: the role of proximity," International Journal of Entrepreneurship and Innovation Management, vol. 7, no. 2-5, pp. 298-319, 2007.
[33] D. E. Super, The Psychology of Careers, John Wiley \& Sons, New York, NY, USA, 1957.

[34] D. T. Hall and J. G. Goodale, Human Resource Management: Strategy, Design, and Mplementation, Scott Foresman, 1986.

[35] K. Weick, "Career as exentric predicates," Executive, vol. 2, pp. 6-10, 1976.

[36] A. Holbrook and D. Wolfe, Eds., Knowledge Clusters and Regional Innovation: Economic Development in Canada, Queen's School of Policy Studies and McGill-Queen's University Press, Kingston, Canada, 2002.

[37] J. N. H. Britton, D. G. Tremblay, and R. Smith, "Contrasts in clustering: the example of Canadian new media," European Planning Studies, vol. 17, no. 2, pp. 211-234, 2009.

[38] K. Acheson and C. J. Maule, "Understanding Hollywood's organization and continuing success," Journal of Cultural Economics, vol. 18, no. 4, pp. 271-300, 1994.

[39] C. Jones and B. B. Lichtenstein, "Temporary inter-organizational projects: how temporal embeddedness enhances coordination and uncertainty," in Handbook of Interorganizational Relations, S. Cropper, M. Ebers, P. S. Ring, and C. Huxham, Eds., Oxford University Press, London, UK, 2008.

[40] C. Dubar, La socialisation. Construction des identités sociales et professionnelles, Armand Colin (Collection U), Paris, France, 1991.

[41] D. Gibson, J. L. Gonzales, and J. Castanon, "The importance of reputation and the role of public relations," Public Relations Quarterly, vol. 51, no. 3, pp. 15-18, 2006.

[42] J. P. Truxillo and P. Corso, Dictionnaire de la Communication, Armand Collin, Paris, France, 1991.

[43] A. Yagoubi, "Performance vécue: la carrière créative des designers de mode à Montréal," in Proceedings of the ARUCGATS Colloquium "Performance, organisation et temps de travail: les défis”, octobre 2011. 


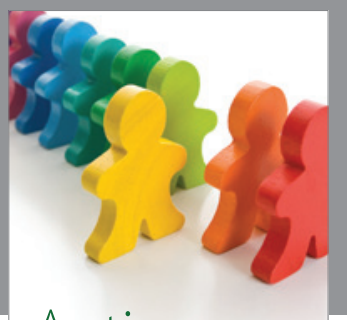

Autism

Research and Treatment
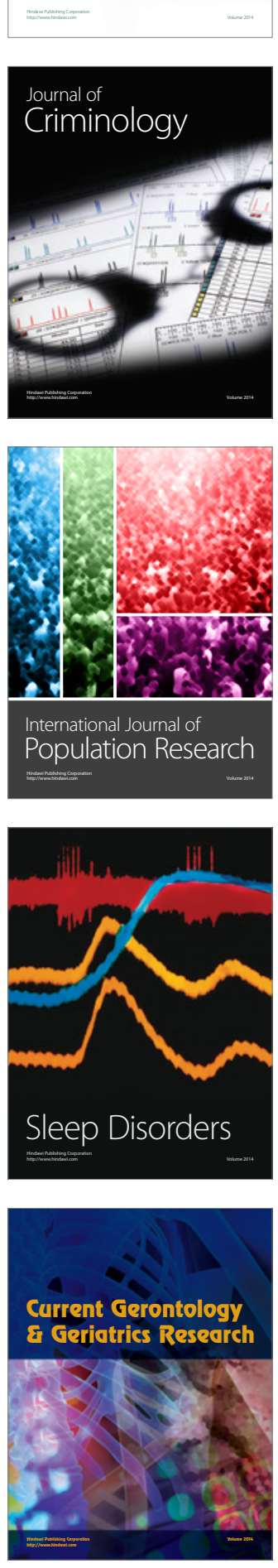
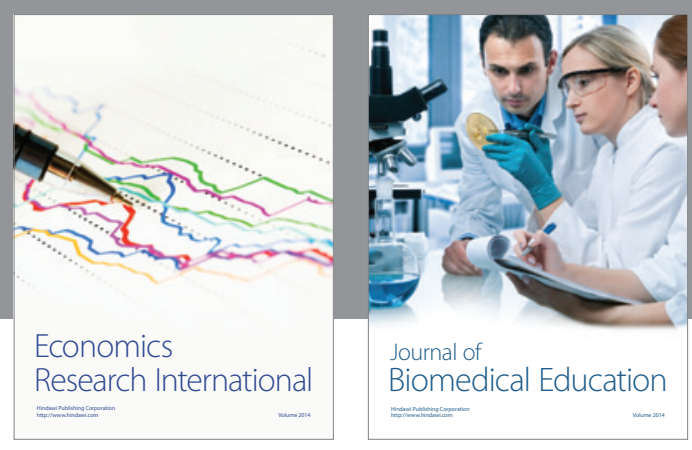

Journal of

Biomedical Education

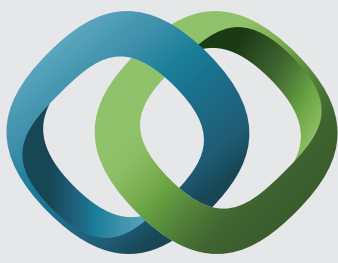

\section{Hindawi}

Submit your manuscripts at

http://www.hindawi.com
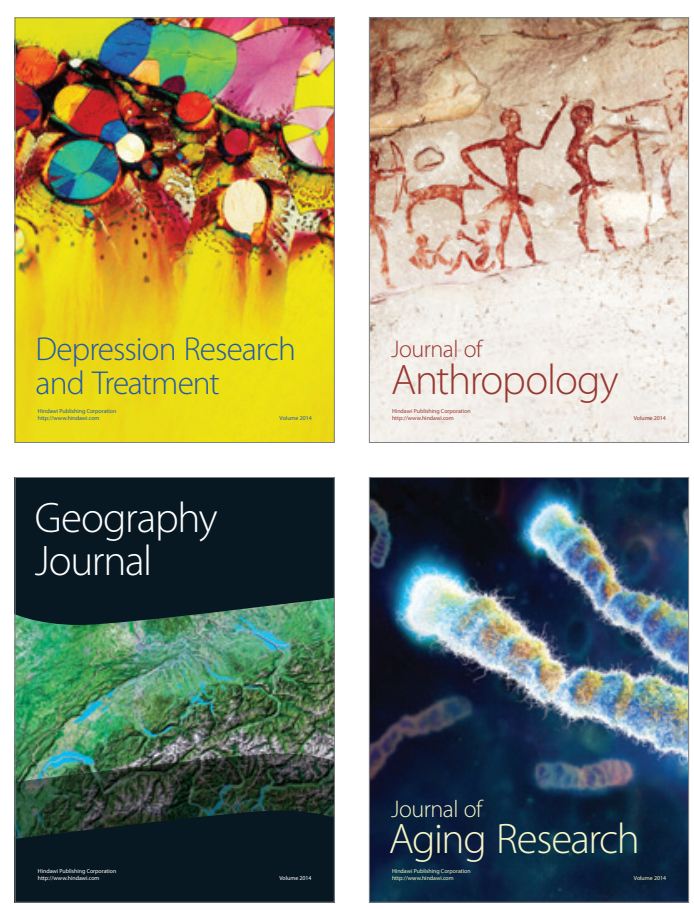

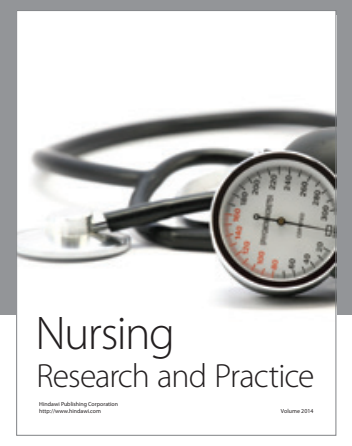

Nursing

Research and Practice

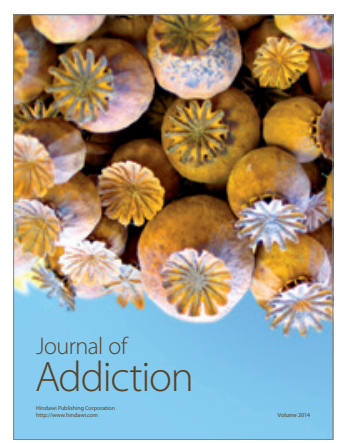

Child Development

Research

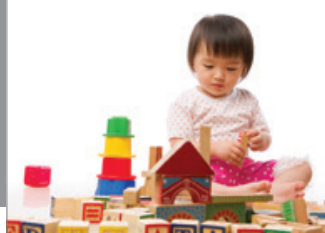

迥
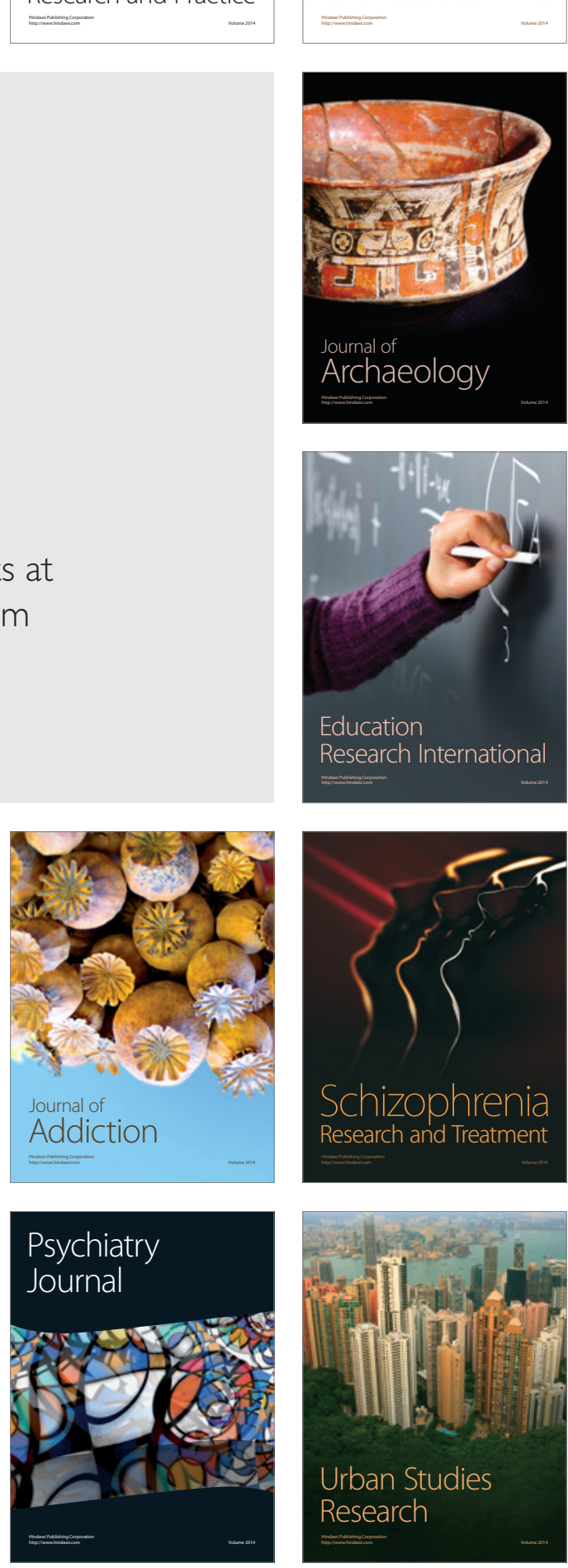